18th Annual Spring Wildflower Pilgrimage.-Plan now to spend April 25-27 in the Great Smoky Mountains at the peak of the spring wildflower season. Although wildflowers will be the principal attraction, Dr. A. Murray Evans, of the University of Tennessee, will lead several fern walks. Motorcades and trail hikes under expert leadership will be offered. Early morning bird walks are planned, as are evening lectures, one of which will be Dr. Evans' "Ferns of the Appalachians."

Participants should register beginning at 9 AM on April 25 in the Gatlinburg Civic Auditorium. The registration fee is \$2.00. There are no advance registrations. Descriptions of the various events will be furnished at registration. For lodging information, write to Department W. P., Box 527, Gatlinburg, Tenn. 37738.

The Fifth Annual Tropical Flower \& Fern Show of the Los Angeles International Fern Society will be held in Brookside Park at Pasadena, California, on Saturday, May 18 (1:00 to 10:00 PM) and on Sunday, May 19 (10:00 A to 6:00 PM). For further details write to Bee Olson, 13715 Cordary Ave., Hawthorne, Calif. 90250.-D.B.L.

\title{
Recent Fern Literature
}

The Southern Fern Guide, by Edgar T. Wherry. Doubleday \& Co., Garden City, New York, 1964. 349 pp. \$4.95.-Through an oversight this important book by one of our Honorary Members has never been reviewed in the Fern Journal. The users of Dr. Wherry's well-known "The Fern Guide" (1961), which covered the northeastern United States, will find this new work familiar, for it follows exactly the same format, and even the same drawings are used when the species concerned occurs both in the northeastern states and in the south. The new illustrations have been drawn by the same artist, are very good, and will serve for the ready identification of all but the most critical species. In my opinion, one of the defects of the new work is that it does not cover all 
of the southern states as is implied by the title. The ferns treated are those occurring south of the Fall Line, from North Carolina south to Florida and west to Texas. Dr. Wherry notes that the ferns of the uplands of North Carolina, Georgia, and Alabama are the same as the more northern ferns treated in his previous "The Fern Guide." This is true, but nevertheless it would have been convenient to have a complete treatment of all the ferns of the southern states. It is true that Wherry mentions, and in some cases illustrates, these northern ferns in an "Appendix," but they are not included in the generic or specific keys, and are not even listed in the Index to the book. This will be a drawback, especially to the amateur. It is possible that this limitation was imposed by the Doubleday Company rather than being voluntary on Dr. Wherry's part, because even as it is the book must be rather expensive to print, with all of its illustrations.

At least some workers have been desirous of having a conservative fern guide to replace that of Small, but they will be disappointed with this, for Wherry recognizes not only most of the segregate genera recognized by Small but some additional ones. Wherry unquestionably knows these southern ferns very well, but he has fallen into the trap of making his generic decisions on the basis of the Florida species only. It is easy enough to recognize segregate genera on the basis of the few Florida representatives of widespread tropical groups, but it is not so easy when these groups are considered from a worldwide viewpoint. It is an essentially provincial attitude. It might be mentioned incidentally that Dr. Wherry lost an opportunity in not segregating the two species he refers to Stenochlaena, S. kunzeana and S. tenuifolia, for Holttum has indicated that the first of these is referable to Lomariopsis, a much better founded segregate than some of those that Wherry does adopt.

Commendably, the Polypodiaceae is kept in its traditional sense, but it is broken up into groups for which "family" names are suggested. Some of these appear to be highly artificial, such as Stenochlaena, Acrostichum, Trismeria, and Pityrogramma being grouped into the "Gymnogrammaceae." A nomenclatural error is 
the restriction of the "family" name Pteridaceae to Pteridium while the type of the family, Pteris, is referred to the "family" Sinopteridaceae. A taxonomic error is the inclusion of patens, augescens, normalis and some other more doubtful species like versicolor in Thelypteris, although in their characters (including chromosome numbers) these are surely referable to Cyclosorus, as Christensen indicated long ago; in fact at least some of them probably hybridize with Cyclosorus dentatus. Incidentally, Wherry recognizes quadrangularis as a species distinct from dentatus, for the first time, so far as I know, for any United States plants. I have tried to follow Alston's suggested distinctions, but they always fail, with African as well as American material.

One weakness is Wherry's desire to provide "common" names for all the species, an idea that goes back to the first edition of Britton and Brown's Illustrated Flora, where common names were invented for all the species, some of them manifestly atrocities. The late Paul C. Standley, when thinking of a local field trip, is reputed to have asked, "Shall we go out and collect Knieskern's smooth-fruited beak-rush?", referring jokingly to the name assigned in Britton and Brown to Rhynchospora knieskernii. Botanists are now generally agreed that it is impossible to get the public to agree on an artificially coined "common" name, and such names have been omitted from the latest Britton and Brown and Gray's Manual. Some of those coined by Wherry are almost unbelievable: "Free-tip star-hair fern," "Toothed lattice-vein fern," "Alabama streak-sorus fern," "Grid-scale maiden fern," "Twin-spore-stalk fern," or "Spready tri-vein fern." I leave the reader to guess, if he can, which species receive these appellations.

One other matter is of some technical importance. On page 346 of the book are published seven new combinations, with the note: "These combinations are also published in periodical literature." Indeed, they were published in the American Fern Journal, vol. 54 , pp. 144-146. But this particular number of the Journal came out November 12, 1964, whereas the Southern Fern Guide, which is dated merely 1964 , was officially published on October 2,1964 . Thus, the new combinations date from it, not from the Journal. 
Wherry spells some specific epithets ferrissi, engelmanni, chapmani, and so forth. He justifies this in the introduction by saying that he adopts the original spelling, not feeling competent to correct the Latin of earlier workers. This is a misapprehension, because no knowledge of Latin is required. The International Code of Botanical Nomenclature specifies that epithets that are genitives of names ending in consonants add "ii," except after "-er," and further that names published originally with other endings are to be treated as orthographic errors and corrected, in these instances to ferrissii, engelmannii, and chapmanii. The amateur or general botanist does not know this and so it is up to a professional like Wherry to adopt the correct spelling. One peculiarity is the reference to the younger Linnaeus as "L. Jr.," but I suppose that this is as good Latin as the usual "L. fil."

Wherry has included a good deal of additional information which will be of value, such as the meaning of specific names, basic chromosome numbers, references to other books on ferns, an article on the life cycle of ferns, notes on fern culture, and incidental notes on a number of cultivated species of ferns.

Some of my remarks above may seem to indicate that I am very critical of this new work. I do wish that it were better in some respects, but nevertheless this is a fine book, the work of a dedicated botanist, and it is going to be the working guide for all students of the southern ferns for many years to come--C.V.M.

\section{American Fern Society}

\section{Report of the President for 1967}

One of the highlights for members of the American Fern Society is the annual meeting in association with the American Institute of Biological Sciences in the summer, which provides an opportunity for fern enthusiasts to get together in an informal manner, to discuss ferns from various points of view, and to observe them in their native habitats. The August field trip to the Edwards Plateau in Texas was exceptionally rewarding, and those who 


\section{$2 \mathrm{BHL}$ Biodiversity Heritage Library}

Morton, C. V. and Wherry, Edgar T. 1968. "The Southern Fern Guide." American fern journal 58, 34-37. https://doi.org/10.2307/1546277.

View This Item Online: https://www.biodiversitylibrary.org/item/100565

DOI: https://doi.org/10.2307/1546277

Permalink: https://www.biodiversitylibrary.org/partpdf/230266

\section{Holding Institution}

Missouri Botanical Garden, Peter H. Raven Library

\section{Sponsored by}

Missouri Botanical Garden

\section{Copyright \& Reuse}

Copyright Status: In copyright. Digitized with the permission of the rights holder.

License: http://creativecommons.org/licenses/by-nc-sa/3.0/

Rights: https://biodiversitylibrary.org/permissions

This document was created from content at the Biodiversity Heritage Library, the world's largest open access digital library for biodiversity literature and archives. Visit BHL at https://www.biodiversitylibrary.org. 